\title{
Mapping absolute migration of global mid-ocean ridges since 80 Ma to Present
}

\author{
Desiderius C. P. Masalu \\ University of Dar Es Salaam, Institute of Marine Sciences, PO Box 668, Zanzibar, Tanzania \\ (Received October 27, 2006; Revised June 8, 2007; Accepted August 2, 2007; Online published September 28, 2007)
}

\begin{abstract}
We have computed and mapped the absolute migration of global mid-ocean ridges in the past 80 m.y. and found that ridges have migrated substantially during that period. Presently, the faster-migrating ridges are Pacific-Antarctic, Central Indian, Southeast Indian, Juan de Fuca, Pacific-Nazca, Antarctic-Nazca and AustraliaAntarctic ridges which migrate between 3.3 and $5.5 \mathrm{~cm} / \mathrm{yr}$. The slower-migrating ridges are Mid-Atlantic and Southwest Indian ridges which migrate between 0.3 and $2.0 \mathrm{~cm} / \mathrm{yr}$. Comparing these results with mantle tomography and geochemistry suggests that slower-migrating ridges have deeper depth of origin than faster-migrating ridges, implying a correlation between migration velocity and depth of origin of ridges. The reconstructed Southwestern Indian ridge (near $44^{\circ} \mathrm{E}$ ) between $60 \mathrm{Ma}$ and Present, lies atop reconstructed Central Indian ridge between 80 and $50 \mathrm{Ma}$, and the present-day Antarctic-Nazca or (Chile) ridge lies atop the reconstructed East Pacific Rise at $70 \mathrm{Ma}$. Furthermore, the South Mid Atlantic Ridge and the East Pacific Rise near $10^{\circ} \mathrm{S}$ appear to have been stationary relative to the mantle for the last $80 \mathrm{~m} . \mathrm{y}$. These observations suggest that different portions of the mantle have undergone different recycling history, and may explain the origin of mantle heterogeneities.
\end{abstract}

Key words: Mid-ocean ridge, tectonics, tomography, absolute migration, melt, magnetic lineations.

\section{Introduction}

Over the past two decades, absolute migration of midocean ridges has been correlated with major observable features of the ridges. For example Stein et al. (1977) correlated spreading asymmetry with migration rate, and Davis and Karsten (1986) explained asymmetry in seamount abundance by absolute ridge migration. Ridge migration rate is also thought to be an important factor that influences the diversity of ridge-crest lavas and the compositional uniformity of ridge-crest basalts (Davis and Karsten, 1986). Rapid migration of mid-ocean ridge has been cited as a possible cause of melting asymmetry (Scheirer et al., 1998; Buck, 1999; Evans et al., 1999). Recently, ridge migration has been used to explain depth and geochemical discontinuities between the southern East Pacific Rise and Antarctic ridges (Small and Danyushevsky, 2003), and the variation in ridge morphology that results from melt focusing across discontinuities (Carbotte et al., 2004). In plate tectonics mid-ocean ridges are considered to be passive features the motions of which are governed by the interactions and motions of global plates, a property that makes absolute migration of ridges, a potential recorder of global tectonics. Despite its apparent importance, mapping of historical absolute migration of mid-ocean ridges has not previously been defined and done. We attempt to compute and map the absolute migration of global mid-ocean ridges since $80 \mathrm{Ma}$.

Copyright (c) The Society of Geomagnetism and Earth, Planetary and Space Sciences (SGEPSS); The Seismological Society of Japan; The Volcanological Society of Japan; The Geodetic Society of Japan; The Japanese Society for Planetary Sciences; TERRAPUB

\section{Method and the Data}

New seafloor forms at mid-ocean ridges when molten magma passively upwells into the narrow space between two diverging plates (Reynolds and Langmuir, 1997; Dziak et al., 2004; Detrick, 2000). Magnetic minerals in the magma align in the direction of the prevailing geomagnetic field, thus recording the age of the new seafloor. Therefore, if we determine the age of the seafloor and can construct a relevant plate motion model in the hotspot reference frame, we can locate the ridge when the seafloor formed. A digital age grid for the world's seafloor with a grid node interval of 6 arc minutes is available (Mueller et al., 1997) which was compiled using the geomagnetic time scale of Cande and Kent (1995) for anomalies younger than chron 34 (83 Ma). Using the digital age grid and models for absolute plate motion of Duncan and Clague (1985) and Mueller et al. (1993) we reconstructed the paleolocations of global mid-ocean ridges from $80 \mathrm{Ma}$ to present, by rotating seafloor age isochrons at intervals of $10 \mathrm{~m}$.y. from their present to their former locations. For detailed investigation of the migration of the ridges we selected 27 ridge segments, picked their corresponding age isochrons on both sides, and reconstructed their paleolocations using the method outlined above and computed the absolute migration speed for each ridge. Two criteria were considered in determining the segments; first the availability of as many as possible identified magnetic isochrons from Chron 34 to Present on both sides of the segment, and secondly, location of the segment on the ridge. Whenever it was possible segments that were about evenly distributed along or located about the centre of the ridge were selected. The aim was to finally get a better estimation of the absolute migra- 


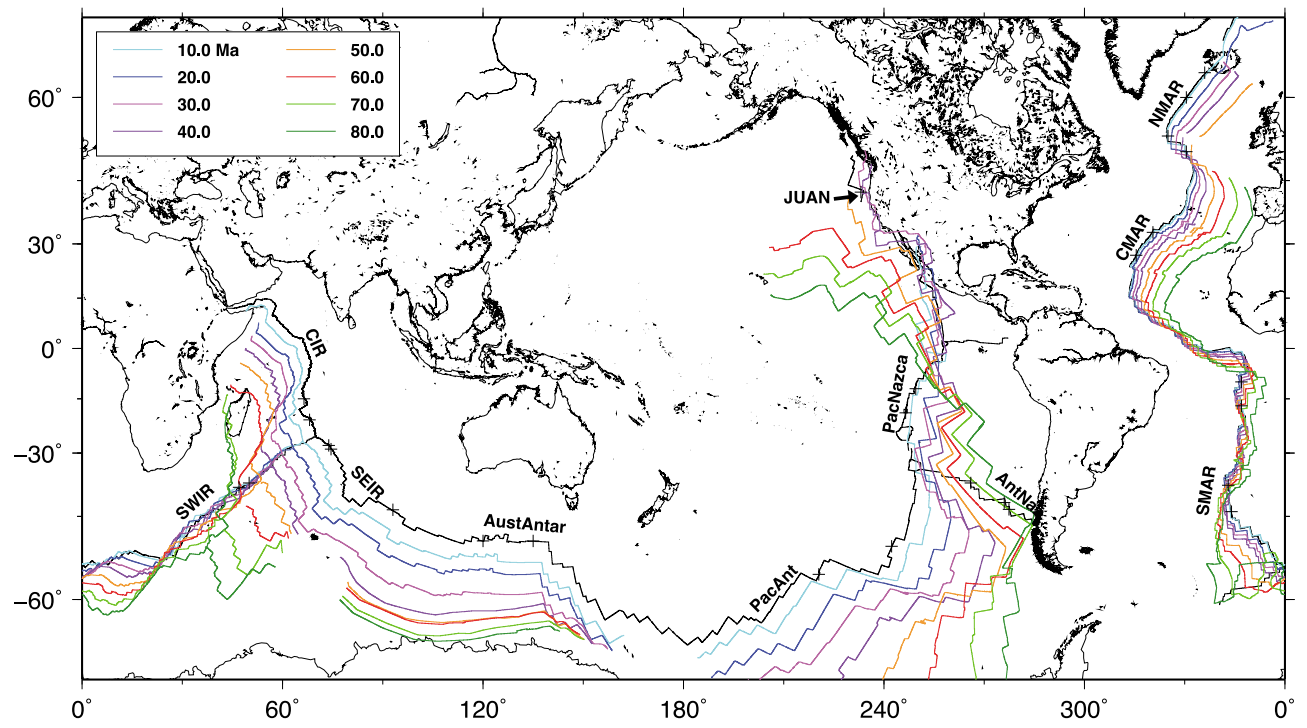

Fig. 1. Absolute migration of global mid-ocean ridges since 80 Ma. Pattern lines are reconstructed past locations of ridges. Numbers in the insert index are years before Present. Crosses show ridge segments used for detailed study and computation of migration speed. Text identifiers are: JUAN (Juan de Fuca ridge), PacAnt (Pacific-Antarctic ridge), PacNazca (Pacific-Nazca ridge), AntNaz (Antarctic-Nazca ridge), SMAR (South Mid-Atlantic Ridge), CMAR (Central Mid-Atlantic Ridge), NMAR (North Mid-Atlantic Ridge), SEIR (Southeast Indian Ridge), CIR (Central Indian Ridge), SWIR (Southwest Indian Ridge) and AustAntar (Australia-Antarctic ridge). Note: For the purpose of this paper the SEIR extends from the Indian Triple Junction to $115^{\circ} \mathrm{E}$ where it joins with the AustAntar.

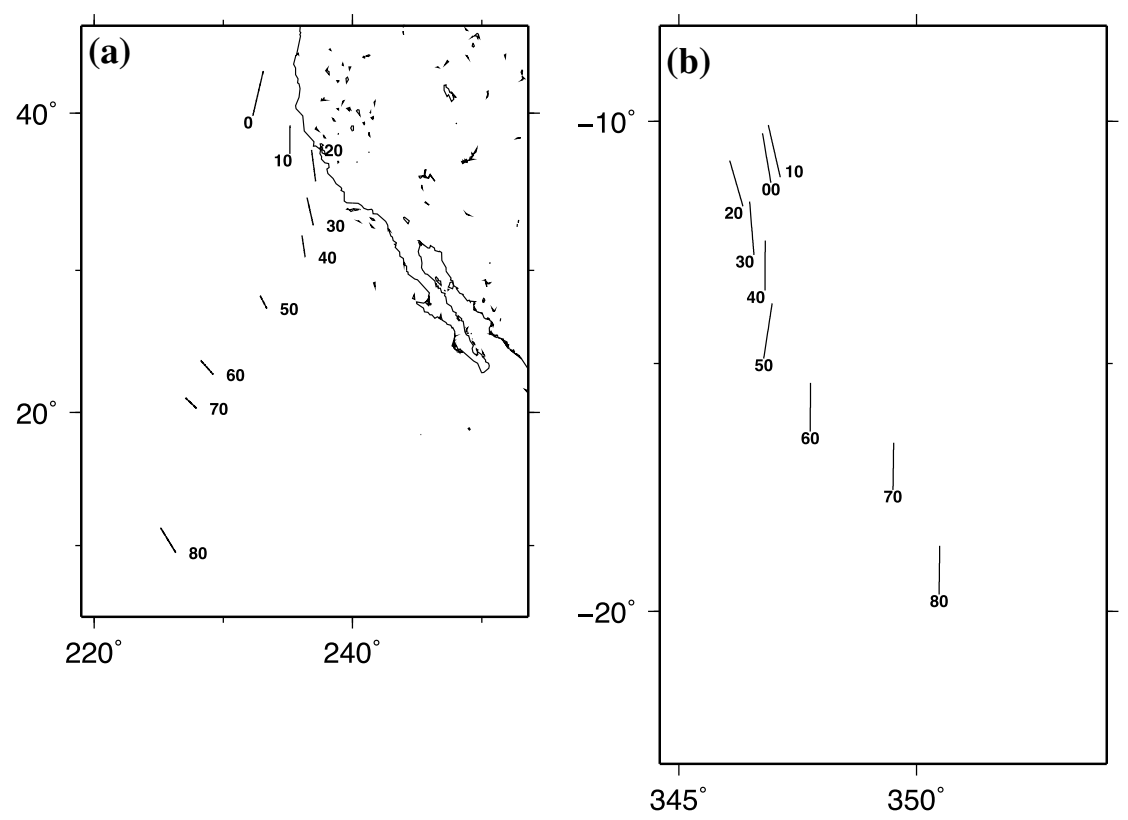

Fig. 2. Absolute migration of some of the selected ridge segments. Solid thick line segments are reconstructed past locations of the ridge segments as indicated by the adjacent number in million years from the present. (a) southernmost segment of the Juan de Fuca ridge, and (b) segment from the SMAR. Other panels as in Fig. 1.

tion speed of the ridge from the stacked absolute migration speed profiles of the segments. This is because absolute migration speed varies at each portion of the ridge. The number of profiles that were stacked for computation of average absolute migration speed and errors for ridges in this study were as follows: Central Indian Ridge-4, Southeast Indian Ridge-6, Southwest Indian Ridge-4, AustraliaAntarctica Ridge-4, Pacific-Antarctica Ridge-4, PacificNazca Ridge-4, Juan de Fucca Ridge-1, AntarcticaNazca Ridge-6, South Mid-Atlantic Ridge-8, Central Mid-Atlantic Ridge-4, and North Mid-Atlantic Ridge-8.
We assume that plates have remained rigid for the past $80 \mathrm{~m} . \mathrm{y}$. This is not very true as both inter- and intra-plate deformation exist (Dixon et al., 1996; Kogan et al., 2000; Beavan et al., 2002; Tregoning, 2002; Socquet et al., 2006) due to differing plate rigidity. There are also inherent errors from the use of absolute plate motion models. These models assume that hotspots are fixed or move only very slowly relative to each other. However, the motion between hotspots remains poorly known and the assumption of hotspot fixity is controversial (Molnar and Stock, 1987; Acton and Gordon, 1994; Tarduno and Gee, 1995). It is known that recon- 


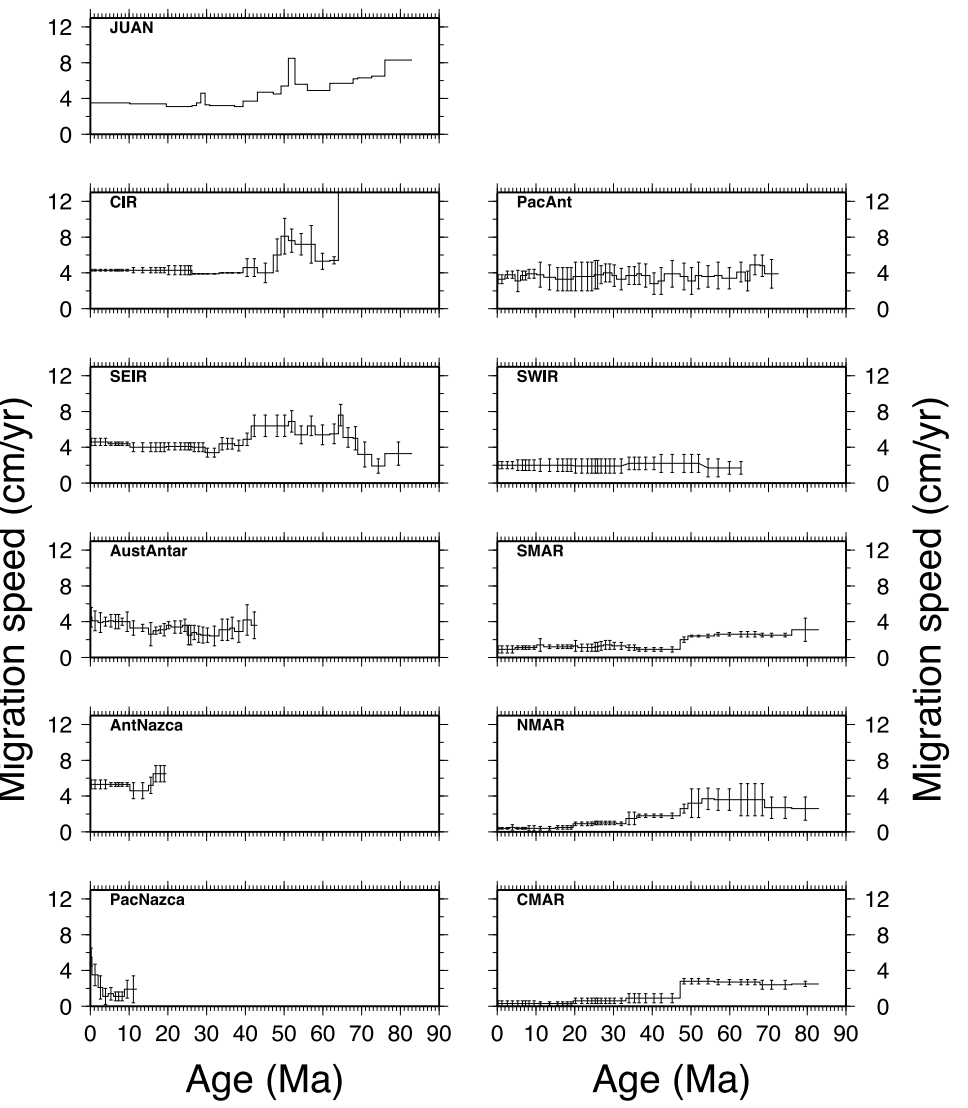

Fig. 3. Stacked profiles of migration speeds of global mid-ocean ridges with errors shown as deviation from the mean. No error bars are shown for JUAN because identified lineations from only one side of the segment were used. Other panels as in Fig. 1.

structions based on the Indo-Atlantic and Pacific hotspots do not agree with each other. This disagreement might indicate that there is a missing plate boundary somewhere, but it could also be that some of the hotspots are moving relative to each other at rates on the order of $20 \mathrm{~mm} / \mathrm{yr}$. Results from the latest IODP cruise (Leg 197) to the Emperor Seamounts suggests that the Hawaiian hotspot was moving southwards from $\sim 81-43 \mathrm{Ma}$ at rates of $30-50 \mathrm{~mm} / \mathrm{yr}$ (Tarduno et al., 2002). Mueller et al. (1993) tried to establish an absolute framework for all plates but were unable to include the Pacific plates in their model. For that reason we use Duncan and Clague (1985) model for Pacific ridges and Mueller et al. (1993) model for all other ridges. Even considering these sources of errors our results appear to be reasonable, and present the first overview of global motion of mid-ocean ridges.

\section{Migration of Global Mid-ocean Ridges}

Our results indicate that global mid-ocean ridges have migrated extensively in the past 80 m.y. (Fig. 1). All ridges appear to be migrating but we also note other observations. The East Pacific Rise or EPR (which includes the PacNazca ridge and its northern adjacent Pacific-Cocos ridge) which was probably one ridge with the Juan de Fuca ridge (JUAN) in the past, appears to have rotated clockwise by about $50^{\circ}$ in the last $80 \mathrm{~m}$.y. and its central section have not migrated extensively. On the other hand the Southern Mid-Atlantic Ridge (SMAR) displays very small lateral migration. However, reconstructions based on the selected ridge segments

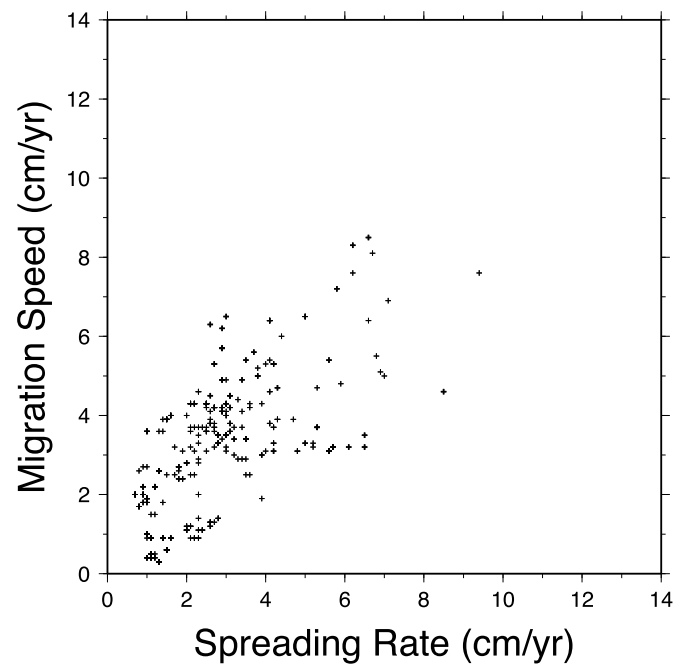

Fig. 4. Absolute migration velocity versus spreading velocity for ridges in this study.

show that the northern EPR and JUAN ridge segments have migrated northward from 80 Ma to Present, and the SMAR appears to be migrating almost northward. The SMAR, during its migratory history ran between several hotspots which may have played a role in limiting lateral migration (Uyeda and Miyashiro, 1974). JUAN appears to be migrating westward since about $20 \mathrm{Ma}$, which may show the end of clockwise rotation of EPR. 
(a)
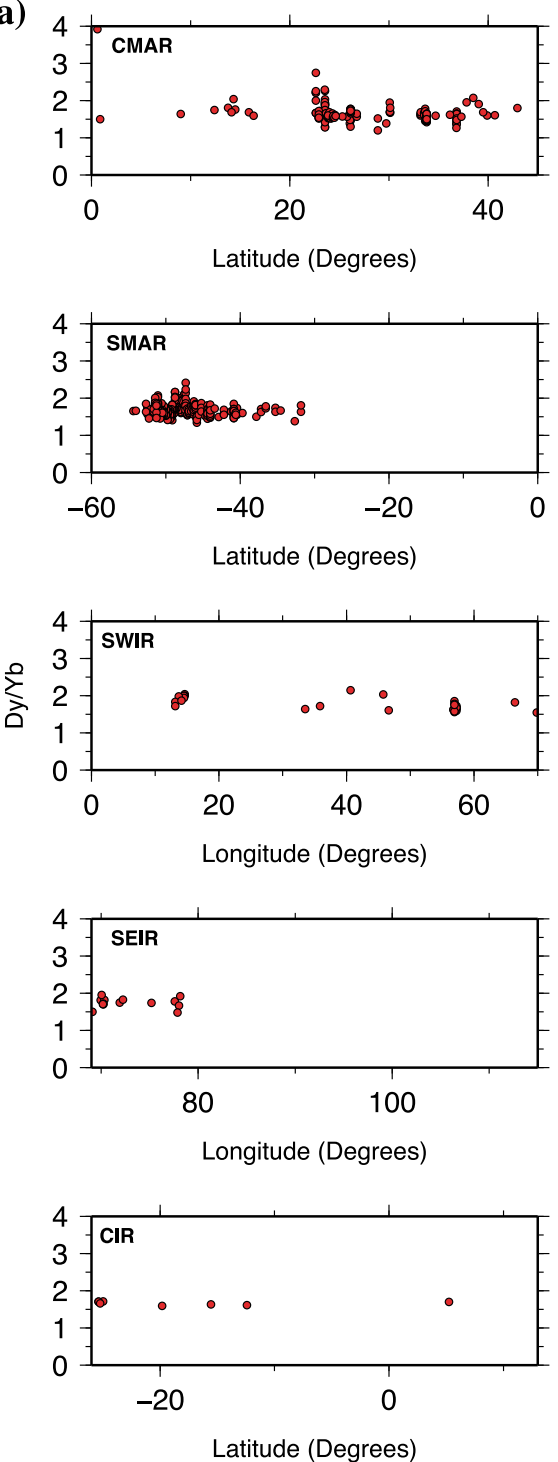
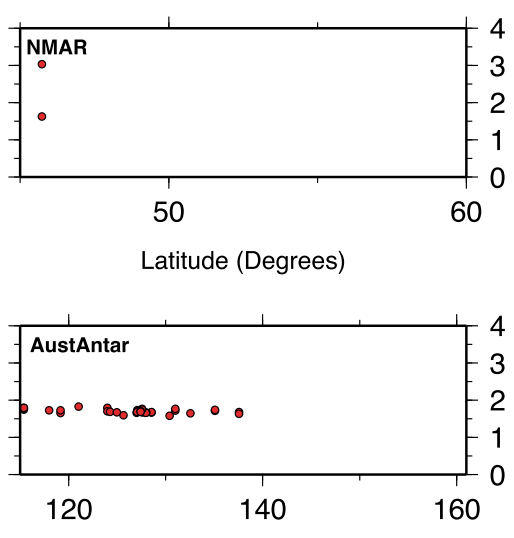

Longitude (Degrees)

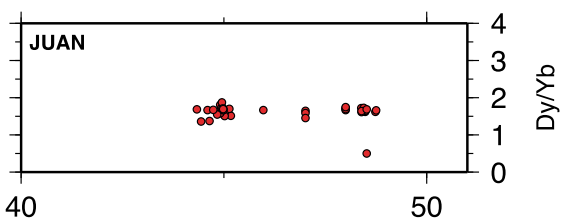

Latitude (Degrees)
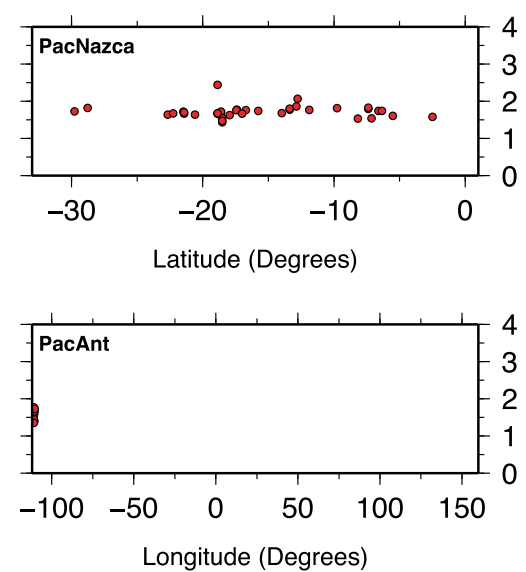

Fig. 5. Dy/Yb ratios of mid-ocean ridges in this study. (a) Along the ridges, and (b) Versus absolute migration speed of ridges. Other panels as defined in Fig. 1. Data from PetDB (http://petdb.ldeo.columbia.edu/petdb).

(b)

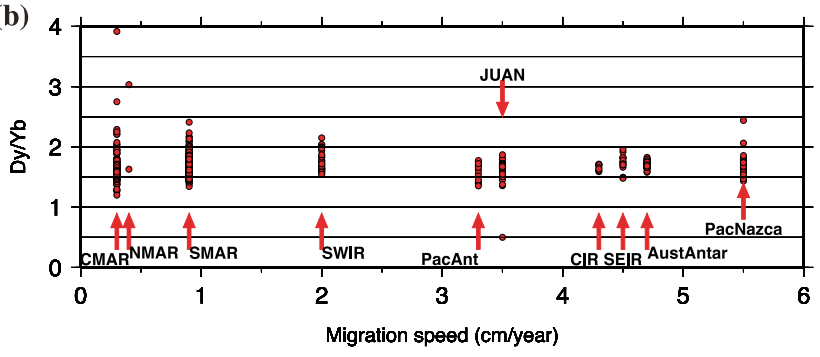

Fig. 5. (continued).

Contrary to SMAR, the Central Mid Atlantic Ridge (CMAR) between the equator and the $40^{\circ} \mathrm{N}$ latitude, and the Northern Mid Atlantic Ridge (NMAR) north of the $40^{\circ} \mathrm{N}$ latitude, have been migrating westerly between $80 \mathrm{Ma}$ and Present (Fig. 1), away from SMAR. The implied location of the boundary between SMAR and CMAR is consistent with the Equatorial Atlantic Region (EAR), an area charac- terized by a dense pattern of mostly medium to large offset fracture zones (Mueller and Smith, 1993). The EAR records a plate boundary between the North and South American plates (Roest and Collette, 1986) that seems has been in existence for the last $80 \mathrm{Ma}$.

\section{Resampling of the Mantle}

Figure 1 shows two more important observations. Firstly, the present-day Chile ridge lies atop the reconstructed EPR at $70 \mathrm{Ma}$, implying that the Chile ridge may be tapping the same portion of the mantle as did the EPR 70 m.y. ago. Similarly, a small section of the reconstructed Southwestern Indian Ridge (SWIR) (near $44^{\circ} \mathrm{E}$ ) between $60 \mathrm{Ma}$ and Present, lies atop the reconstructed Central Indian Ridge (CIR) between 80 and $50 \mathrm{Ma}$. This implies since $60 \mathrm{Ma}$ to Present, that section of the SWIR may be tapping the same portion of the mantle as did the CIR between 80 and 50 Ma. Secondly, while all ridges appear to be migrating relative to the mantle for the last $80 \mathrm{Ma}$, the SMAR and EPR near $10^{\circ} \mathrm{S}$ appear to have been stationary during that period. 
This implies that these ridges have been sampling same locations of the mantle for the last $80 \mathrm{Ma}$. These observations suggest that different portions of the mantle have undergone different recycling history, and may have important thermochemical implications for the mantle. They thus offer a possible mechanism of origin of lateral heterogeneities in the mantle, and variations of the chemistry of global mid-ocean ridges (e.g., Graham et al., 2001). It is important to note here that the exact relative motion between the plates, upper mantle and lower mantle is not known. However, relative to the lower mantle the plates and the upper mantle move in opposite directions, to a large extent cancelling each other out (e.g., Argus and Gross, 2004). The relative motions between plates, upper mantle and lower mantle may thus not greatly affect the above results.

\section{Absolute Migration Speed and Mantle Tomog- raphy}

Absolute migration speed of ridges that were investigated are shown in Fig. 3. The ridges divide into two groups: the slower-migrating ridge group including the CMAR, SMAR, NMAR and SWIR ridges, and the faster-migrating ridge group which includes all other ridges. Presently, the slower-migrating ridges migrate between 0.3 and $2.0 \mathrm{~cm} / \mathrm{yr}$ whereas the faster-migrating ridges migrate between 3.3 and $5.5 \mathrm{~cm} / \mathrm{yr}$.

We compare our results with seismic velocity anomalies beneath global mid-ocean ridges. Su et al. (1992) show that seismic velocity anomalies associated with midocean ridges, appear as continuous features to $300 \mathrm{~km}$ depth. For the NMAR, SMAR, Pacific-Antarctic ridge (PacAnt), SWIR, and Carlsberg ridges, mantle velocities remain slower than normal on average down to at least $400 \mathrm{~km}$ depth, and may persist to $600 \mathrm{~km}$ depth. Except for the PacAnt, 'deep-rooted' ridges are the slower migrating (Fig. 3). Although falls in the faster-migrating ridges group, the PacAnt is the slowest in the group. So, the cutoff point between "faster" and "slower" migrating ridges may be $\sim 3.5 \mathrm{~cm} / \mathrm{yr}$ which seems to be consistent with the velocity found by Small and Sandwell (1994) which distinguishes between mid-ocean ridges that have a ridge-crest versus those that have a median valley. This is supported by the observation that migration velocity of ridges increase proportionally with spreading velocity (Fig. 4). These results imply a possible correlation between absolute migration speed and depth of origin of mid-ocean ridges whereby faster-migrating ridges have shallow depth of origin while slower-migrating ridges have deeper depth of origin. This suggests that slower migrating ridges allow the development of stable and deep rooted mantle convection cells beneath them; whereas faster migrating ridges probably cause some disturbances to mantle convection cells beneath them, thus allow only development of shallow rooted convection cells. Unfortunately, the resolutions of the currently available models of mantle tomography do not allow us to directly quantify this apparent correlation. Furthermore, this study cannot strictly distinguish between the two possibilities, that is, the slower migrating ridges have deeper origins because they are migrating more slowly or, are they migrating more slowly because they have deeper origins.

\section{Discussion}

One of the most important dynamic processes in the Earth's interior is thermal convection in the mantle. Two methods are used to study temperature variations in the upper mantle: study of trace- and major-element chemistry of basalts erupted at mid-ocean ridges which is directly influenced by the temperature of the mantle beneath (e.g., Klein and Langmuir, 1987; Hellebrand et al., 2001; Humler and Besse, 2002) and seismic velocity studies (e.g., Su et al., 1992; Zhang and Tanimoto, 1992).

Klein and Langmuir $(1987,1989)$ studied the chemical systematics of global Mid-Ocean Ridge Basalts (MORB) and explained them by variations among different melting columns. In their model, hotter mantle material (from deeper depth) intersects the solidus at greater depth and produces a taller melting column, leading to greater mean pressures and extent of melting whereas cooler mantle material (from shallow depth) intersects the solidus at shallower depth and produces a shorter melting column, leading to lower mean pressures and extent of melting. This model can be combined with our results whereby, faster-migrating ridges correspond to ridges with cooler mantle sources and slower-migrating ridges correspond to ridges with hotter mantle sources. The combined result suggests that the mantle beneath faster-migrating ridges have undergone smaller extents of melting whereas that beneath slower-migrating ridges have undergone greater extents of melting which may influence their chemistry.

Furthermore, during the creation of new Earth crust at mid ocean ridges, melt from the partially melted fertile upper mantle is extracted to the spreading centre, and the residual depleted mantle flows horizontally away (Martinez and Taylor, 2002; Hauri, 1999; Benoit et al., 1999). This model when considered with our results has important implications. Firstly, the observation that the SWIR and present-day AntNazca (also known as Chile ridge) appear to be tapping portions of the mantle as other ridges did in the past suggests that basalts from these ridges may record two or more phases of recycling or the combined effect. They may show greater extents of melting and/or may be more depleted. Secondly, our result show that two sections of the global mid-ocean ridge system, the SMAR and EPR near $10^{\circ} \mathrm{S}$, have remained stationary for the last $80 \mathrm{~m}$.y. Because these ridges have been sampling same portions of the mantle for a long time, may be sampling deeper mantle and their chemistry may be different from the rest of the ridges that have been migrating.

We have computed the $\mathrm{Dy} / \mathrm{Yb}$ ratios of mid-ocean ridges in this study except only for the AntNaz ridge for which data were not available (Fig. 5(a)). Higher Dy/Yb ratios indicate melt originating at greater mantle depths owing to the presence of residual garnet (Carbotte et al., 2004). Disregarding points that are clearly outlier, the $\mathrm{Dy} / \mathrm{Yb}$ ratio ranges vary as follows: SWIR, 1.55-2.15; SEIR, 1.48-1.96; CIR, 1.59-1.71; AustAntar, 1.58-1.83; NMAR, 1.63 (only two data points available); CMAR, 1.2-2.75; SMAR, 1.342.41; PacAnt, 1.35-1.77; PacNaz, 1.43-2.44; and JUAN, 1.36-1.87. The slower-migrating mid-ocean ridges, i.e., the NMAR, CMAR, SMAR and SWIR, and the sections of mid-ocean ridges that have remained stationary at least 
since 80 Ma, i.e., SMAR and PacNaz (which corresponds to the location where the EPR have remained stationary) have the highest upper ranges of the $\mathrm{Dy} / \mathrm{Yb}$ ratios indicating they are sampling deeper mantle than the other ridges (Fig. 5(b)).

\section{Conclusions}

We have computed and mapped the absolute migration of global mid-ocean ridges for the past 80 m.y. Absolute migration speed and depth of origin of ridges appear to correlate whereby slower-migrating ridges have deeper depth of origin than faster-migrating ridges. The cutoff point between "faster" and "slower" migrating ridges is $\sim 3.5 \mathrm{~cm} / \mathrm{yr}$. The SWIR and present-day Chile ridge appear to be tapping portions of mantle as other ridges did in the past, and the SMAR and EPR near $10^{\circ} \mathrm{S}$ appear to have been stationary relative to the mantle for the last $80 \mathrm{~m}$.y. This suggests that different portions of the mantle have undergone different recycling history.

Acknowledgments. I thank C Small, and L Lawver for their constructive comments that helped in improving this paper. I also thank S Uyeda and W Sager for their advice that shaped the original version of this paper. This work was mainly supported by the Japan Society for the Promotion of Science (JSPS). The Japan Students Service Organization (JASSO) also partially supported this work through a fellowship to the author to complete the work at the Department of Geosystem Engineering, Graduate School of Engineering, University of Tokyo in Professor Kensaku Tamaki's laboratory.

\section{References}

Acton, G. D. and R. G. Gordon, Paleomagnetic tests of Pacific plate reconstructions and implications for motion between hotspots, Science, 263, 1246-1254, 1994.

Argus, D. F. and R. S. Gross, An estimation of motion between the spin axis and the hotspots over the past century, Geophys. Res. Lett., 31, L06614, doi:10.1029/2004GL019657, 2004.

Beavan, J., P. Tregoning, M. Bevis, T. Kato, and C. Meertens, Motion and rigidity of the Pacific Plate and implications for plate boundary deformation, J. Geophys. Res., 107, 2261, doi:10.1029/2001JB000282, 2002.

Benoit, M., G. Ceuleneer, and M. Polve, The remelting of hydrothermally altered peridotite at mid-ocean ridges by intruding mantle diapirs, $\mathrm{Na}$ ture, 402, 514-518, 1999.

Buck, R., Mapping mantle melting, Science, 286, 692, 1999.

Cande, S. C. and D. V. Kent, Revised calibration of the geomagnetic time scale for the late Cretaceous and Cenozoic, J. Geophys. Res., 100, 60936098, 1995.

Carbotte, S. M., C. Small, and K. Donnelly, The influence of ridge migration on the magmatic segmentation of mid-ocean ridges, Nature, $\mathbf{4 2 9}$, 743-746, 2004.

Davis, E. E. and J. L. Karsten, On the cause of the asymmetric distribution of seamounts about the Juan de Fuca ridge: ridge-crest migration over a heterogeneous asthenosphere, Earth Planet. Sci. Lett., 79, 385-396, 1986.

Detrick, R. S., Portrait of a magma chamber, Nature, 406, 578-579, 2000.

Dixon, T. H., A. Mao, and S. Stein, How rigid is the stable interior of the North American plate?, Geophys. Res. Lett., 23, 3035-3038, 1996.

Duncan, R. A. and D. A. Clague, Pacific plate motion recorded by linear volcanic chains, in The Ocean Basins and Margins, 7A, pp. 89-121, edited by A. E. M. Nairn et al., Plenum Publishing, New York, 1985.

Dziak, R. P., D. K. Smith, D. R. Bohnenstiehl, C. G. Fox, D. Desbruyeres, H. Matsumoto, M. Tolstoy, and D. Fornari, Evidence of a recent magma dike intrusion at the slow spreading Lucky Strike segment, Mid-Atlantic Ridge, J. Geophys. Res., 109, doi:10.1029/2004JB003141, 2004.

Evans, R. L., P. Tarits, A. D. Chave, A. White, G. Heinson, J. H. Filloux, H. Toh, N. Seama, H. Utada, J. R. Booker, and M. J. Unsworth, Asym- metric electrical structure in the mantle beneath the East Pacific Rise at $17^{\circ} \mathrm{S}$, Science, 286, 752-756, 1999.

Graham, D. W., J. E. Lupton, F. J. Spera, and D. M. Christie, Upper-mantle dynamics revealed by helium isotope variations along the southeast Indian ridge, Nature, 409, 701-703, 2001.

Hauri, E., Mid-ocean ridges-One more time, from the top, Nature, 402 469-471, 1999.

Hellebrand, E., J. E. Snow, H. J. B. Dick, and A. W. Hofmann, Coupled major and trace elements as indicators of the extent of melting in midocean ridge peridotites, Nature, 410, 677-681, 2001.

Humler, E. and J. Besse, A correlation between mid-ocean ridge basalt chemistry and distance to continents, Nature, 419, 607-609, 2002.

Klein, E. M. and C. H. Langmuir, Global correlations of ocean ridge basalt chemistry with axial depth and crustal thickness, J. Geophys. Res., 92 , 8089-8115, 1987.

Klein, E. M. and C. H. Langmuir, Local versus global variations in ocean ridge basalt composition: A reply, J. Geophys. Res., 94, 4241-4252, 1989.

Kogan, M. G., G. M. Steblov, R. W. King, T. A. Herring, D. I. Frolov, S. G Egorov, V. Levin, A. Lerner-Lam, and A. Jones, Geodetic constraints on the rigidity and relative motion of Eurasia and North America, Geophys Res. Lett., 27, 2041-2044, 2000.

Martinez, F. and B. Taylor, Mantle wedge control on back-arc crustal accretion, Nature, 416, 417-420, 2002.

Molnar, P. and J. Stock, Relative motions of hotspots in the Pacific, Atlantic, and Indian Oceans since late Cretaceous time, Nature, 327, 587591, 1987.

Mueller, R. D. and W. H. F. Smith, Deformation of the oceanic crus between the North American and South American plates, J. Geophys. Res., 98, 8275-8291, 1993.

Mueller, R. D., J.-Y. Royer, and L. A. Lawver, Revised plate motions relative to hotspots from combined Atlantic and Indian Ocean hotspot tracks, Geology, 21, 275-278, 1993.

Mueller, R. D., W. R. Roest, J.-Y. Royer, L. M. Gahagan, and J. G. Sclater, Digital isochrons of the world's ocean floor, J. Geophys. Res., 102, 3211-3214, 1997.

Reynolds, J. R. and C. H. Langmuir, Petrological systematics of the MidAtlantic Ridge south of Kane: Implications for ocean crust formation, $J$. Geophys. Res., 102, 14,915-14,946, 1997.

Roest, W. R. and B. J. Collette, The fifteen twenty fracture zone and the North American-South American plate boundary, J. Geol. Soc. London, 143, 833-843, 1986

Scheirer, D. S., D. W. Forsyth, M.-H. Cormier, and K. C. Macdonald, Shipboard geophysical indications of asymmetry and melt production beneath the East Pacific Rise near the MELT experiment, Science, 280 1221-1224, 1998.

Small, C. and L. V. Danyshevsky, Plate-kinetmatic explanation for midocean ridge depth discontinuities, Geology, 31, 399-402, 2003.

Small, C. and D. T. Sandwell, Imaging mid-ocean ridge transitions with satellite gravity, Geology, 22, 123-126, 1994.

Socquet, A., C. Vigny, N. Chamot-Rooke, W. Simons, C. Rangin, and B. Ambrosius, India and Sunda plates motion and deformation along their boundary in Myanmar determined by GPS, J. Geophys. Res., 111, B05406, doi:10.1029/2005JB003877, 2006.

Stein, S., H. J. Melosh, and J. B. Minster, Ridge migration and asymmetric sea-floor spreading, Earth Planet. Sci. Lett., 36, 51-62, 1977.

Su, W., R. L. Woodward, and A. M. Dziewonski, Deep origin of mid-ocean ridge seismic velocity anomalies, Nature, 360, 149-152, 1992.

Tarduno, J. A. and J. Gee, Large-scale motion between Pacific and Atlantic hotspots, Nature, 378, 477-480, 1995.

Tarduno, J. A., R. A. Duncan, and D. W. Scholl, Motion of the Hawaiian Hotspot: A Paleomagnetic Test-Sites 1203-1206, Proc. ODP, Vol. 197 Init. Rep., ODP Texas A\&M University, Texas, 2002. Also available online at: http://www-odp.tamu.edu/publications/197_IR/197ir.htm.

Tregoning, P., Plate kinematics in the Western Pacific derived from geodetic observations, J. Geophys. Res., 107, doi:2001JB000406, 2002.

Uyeda, S. and A. Miyashiro, Plate tectonics and the Japanese islands: A synthesis, Geol. Soc. America Bull., 85, 1159-1170, 1974.

Zhang, Y.-S. and T. Tanimoto, Ridges, hotspots and their interpretation as observed in seismic velocity maps, Nature, 355, 45-49, 1992

D. C. P. Masalu (e-mail: masalu@ims.udsm.ac.tz) 